\title{
Manajemen Asuhan Kebidanan Antenatal pada Ny "S" dengan Hiperemesis Gravidarum Tingkat II di RS TNI Angkatan Laut Jala Ammari pada Tanggal 27 Mei-18 Juli 2018
}

\author{
${ }^{1}$ Evi Susanti, ${ }^{2}$ Firdayanti, ${ }^{3}$ Nadyah Haruna
}

\begin{abstract}
ABSTRAK
Kehamilan pada umumnya akan berlangsung normal sebanyak $80-90 \%$ dan hanya $10-12 \%$ kehamilan yang berkembang menjadi patologis. Salah satunya yaitu hiperemesis gravidarum dimana ibu mengalami mual dan muntah lebih dari 10 kali dalam 24 jam sehingga mengganggu aktifitas sehari-hari dan keadaan umum menjadi buruk. Hiperemesis gravidarum terbagi menjadi 3 tingkatan, yaitu tingkat I, II, dan III.
\end{abstract}

Studi kasus pada Ny "S" dengan hiperemesis gravidarum tingkat II di RS TNI-AL Jala Ammari menggunakan pendekatan dengan metode manajemen asuhan kebidanan tujuh langkah Varney. Asuhan dilakukan selama 3 hari perawatan di RS dengan memberikan pemenuhan kebutuhan dasar, cairan, obat-obatan, vitamin, support psikologis maupun spiritual. Kemudian melakukan kunjungan rumah selama \pm 8 minggu sebanyak 5 kali kunjungan.

Evaluasi studi kasus menunjukkan bahwa setelah dilakukan perawatan di RS dan kunjungan rumah, mual dan muntah ibu teratasi, tidak ada penurunan berat badan (BB), dan pembesaran perut sesuai usia kehamilan ibu. Telah dilakukan pendokumentasian semua temuan dan tindakan yang telah dilakukan pada ibu
*UIN Alauddin Makassar

*susantievi077@gmail.com

*firdayanti@uin-alauddin.ac.id

*nadyaharuna@gmail.com

Kata kunci :

Kehamilan;

Hiperemesis Gravidarum

Tingkat II;

Langkah Varney

\section{PENDAHULUAN}

Federasi Obstetri Ginekologi Internasional mendefinisikan kehamilan sebagai fertilisasi atau penyatuan dari spermatozoa dan ovum lalu dilanjutkan dengan nidasi dan implantasi. Bila dihitung dari saat fertilisasi hingga lahirnya bayi, kehamilan normal akan berlangsung dalam waktu 40 minggu atau 10 bulan atau 9 bulan menurut kalender internasional.

Pada umumnya $80-90 \%$ kehamilan akan berlangsung normal dan hanya $10-12 \%$ kehamilan yang disertai dengan penyulit atau berkembang menjadi kehamilan patologis. Salah satu yang sering terjadi pada ibu hamil akibat langsung dari kehamilan adalah mual dan muntah. Nausea (mual) dan emesis (muntah) pada umumnya terjadi pada bulan- bulan pertama kehamilan, dan kadang- kadang disertai oleh emesis. Keadaan ini lazim disebut dengan morning sickness. Kondisi morning sickness ini merupakan salah satu gejala paling 
awal dalam kehamilan yang terjadi pada trimester I dan trimester ke II, tapi juga dapat berlangsung sampai 4 bulan kehamilan (Rukiah, Y, 2013: 79).

Ibu yang mengalami mual muntah biasanya cenderung malas makan. Padahal ibu hamil memerlukan asupan nutrisi yang lebih. Selain untuk kesehatan dirinya, juga untuk janinnya agar tetap sehat. Dalam batas- batas tertentu, keadaan ini masih fisiologis. Namun, bila sangat sering dan mengganggu aktifitas sehari-hari ibu hamil, dapat mengakibatkan gangguan kesehatan. Hal inilah yang kemudian disebut dengan hiperemesis gravidarum (Rukiah, Y, 2013: 79). Hiperemesis gravidarum adalah keadaan dimana penderita mual dan muntah lebih dari 10 kali dalam 24 jam, sehingga pekerjaan sehari-hari terganggu dan keadaan umum menjadi buruk. Keadaan ini rata-rata muncul pada usia kehamilan 8-12 minggu (Susilawati dan Erlina, 2017).

Hiperemesis gravidarum adalah mual dan muntah yang berlebihan pada wanita hamil sampai mengganggu pekerjaan sehari- hari karena umumnya menjadi buruk, karena terjadi dehidrasi. Penyebab hiperemesis gravidarum belum diketahui secara pasti, namun diperkirakan disebabkan oleh adanya peningkatan hormon estrogen dan HCG (Hormon Chorionic Gonadothrophin) dalam serum. Pada umumnya wanita dapat menyesuaikan diri dengan keadaan ini, meskipun demikian gejala mual dan muntah yang berat dapat berlangsung sampai 4 bulan. Sehingga, pekerjaan sehari-hari menjadi terganggu dan keadaan umum menjadi buruk (Nadyah, 2013: 38).

Hiperemesis gravidarum ini pada umumnya dialami oleh ibu primigravida sebanyak 60-80\%, dan multigravida sebanyak 40-60\%. Menurut WHO sebagai badan perserikatan bangsa-bangsa (PBB) yang menangani masalah bidang kesehatan, mengatakan bahwa hiperemesis gravidarum terjadi di seluruh dunia, di antaranya negara- negara benua Amerika dengan angka kejadian yang beragam yaitu mulai $0,5-2 \%$, sebanyak $0,3 \%$ di Swedia, $0,5 \%$ di California, 0,8\% di Canada, 10,8\% di China, 0,9\% di Norwegia, 2,2\% di Pakistan, dan 1,9\% di Turki. Sedangkan angka kejadian hiperemesis gravidarum di Indonesia adalah mulai dari 1-3\% dari seluruh kehamilan. Perbandingan insidensi secara umumnya yaitu $4: 1000$ (Atika, Hardians, dkk, 2016).

Berdasarkan data ibu hamil dengan komplikasi di RS TNI-AL Jala Ammari, jumlah ibu hamil dengan hiperemesis gravidarum pada tahun 2015 yaitu sebanyak 23 orang (10,26\%), 
kemudian pada tahun 2016 terjadi peningkatan yaitu sebanyak 41 orang (12,85\%), dan semakin meningkat pada tahun 2017 yaitu sebanyak 54 orang (17,25\%). Dampak dari hiperemesis gravidarum dapat terjadi pada ibu dan janin, seperti ibu akan kekurangan nutrisi dan cairan sehingga keadaan fisik ibu menjadi lemah dan lelah, penurunan berat badan (5\% dari berat badan awal), dehidrasi, ketosis, gangguan asam basa, pneumoni aspirasi, robekan mukosa esofagus, kerusakan hepar dan kerusakan ginjal.

Hiperemesis gravidarum tidak hanya berdampak pada ibu, tapi juga berdampak pada janinnya. Seperti abortus, bayi berat lahir rendah (BBLR), kelahiran prematur, serta malformasi pada bayi baru lahir. Selain itu, kejadian pertumbuhan janin terhambat (Intrauterine Growth Retardation/IUGR) meningkat pada wanita hamil dengan hiperemesis gravidarum (Ardani, 2013). Jika ibu yang mengalami hiperemesis gravidarum dibiarkan begitu saja, maka kebutuhan nutrisi yang dibutuhkan ibu hamil menjadi tidak terpenuhi. Jika kebutuhan nutrisi tidak terpenuhi, dapat mengganggu kesehatan dan aktifitas ibu hamil. Padahal, nutrisi mempunyai peran penting dalam kehamilan. Terutama pada kesehatan ibu dan pertumbuhan janinnya agar tetap sehat.

Berdasarkan uraian dan data di atas, kita dapat mengetahui bahwa hiperemesis gravidarum memang sangat banyak dialami oleh ibu hamil. Sehingga memerlukan pencegahan dan penanganan sedini mungkin agar tidak menimbulkan komplikasi yang berbahaya bagi ibu maupun janinnya. Atas dasar pemikiran itulah, sehingga penulis tertarik untuk melakukan manajemen asuhan kebidanan dengan kasus hiperemesis gravidarum tingkat II di RS TNI-AL Jala Ammari

\section{METODE PENELITIAN}

Jenis penelitian ini adalah studi kasus dengan pendekatan manajemen asuhan kebidanan sesuai dengan 7 langkah Varney dan pendokumentasian dalam bentuk SOAP

\section{HASIL PENELITIAN}

Penelitian ini dilakukan di RS TNI Angkatan Laut Jala Ammari pada tanggal 27 Mei 18 Juli 2018 tentang asuhan kebidanan antenatal pada Ny "S" dengan hiperemesis gravidaru tingkat II. Pembahasan ini dibuat berdasarkan landasan teoritis dan studi kasus yang dapat dianalisa secara teoritis untuk memudahkan memahami antara kesenjangan dan kesesuaian 
yang terjadi pada kasus ini dengan berdasarkan pada pendekatan asuhan kebidanan dengan tujuh langkah varney yakni : pengumpulan data dasar, merumuskan diagnosis atau masalah potensial, melaksanakan tindakan segera atau kolaborasi, merencanakan tindakan asuhan kebidanan, dan evaluasi

\section{PEMBAHASAN}

Berikut ini akan diuraikan pembahasan berdasarkan tiap langkah dari 7 langkah Varney:

\section{A. Langkah I : Identifikasi Data Dasar}

Langkah ini bertujuan untuk mengumpulkan data subjektif dan objektif. Studi kasus ini dilakukan pada Ny "S". Dari hasil anamnesis, ibu mengatakan bahwa ia mengalami mual dan muntah sejak 2 bulan yang lalu. Ibu mengatakan bahwa sebelumnya ia sudah pernah dirawat di RS TNI-AL Jala Ammari dengan keluhan yang sama, yaitu pada tanggal 24-27 April 2018. Akan tetapi, waktu itu ibu belum mengetahui bahwa dirinya sedang hamil. Ibu mengatakan ini merupakan kehamilan yang tidak direncanakan.

Ibu mengatakan bahwa ia muntah sekitar $\pm 5-6$ kali dalam sehari. Namun, keluhan ibu terus bertambah hingga mual dan muntah tersebut mencapai \pm 10 kali dalam sehari dan hal itu mengganggu aktifitas ibu sejak 2 hari yang lalu. Ibu juga merasa pusing, lemas, dan nyeri ulu hati

Selain itu, ibu juga mengatakan bahwa ibu memang pernah mengalami hiperemesis gravidarum pada kehamilan sebelumnya. Saat ini ibu memasuki usia 37 tahun, ibu mengatakan bekerja sebagai ibu rumah tangga biasa yang mengerjakan pekerjaan sehari-hari sendiri. Setelah dilakukan anamnesis, selanjutnya dilakukan pemeriksaan fisik.. Keadaan umum ibu tampak lemah, kesadaran apatis (acuh tak acuh), turgor kulit kurang baik, BB ibu $52 \mathrm{~kg}$, tekanan darah 80/60 mmHg, mata tampak cekung, sklera sedikit icterus.

Konjungtiva tampak pucat, bibir kering, dan lidah tampak kotor. Pada pemeriksaan abdomen, TFU 3 jari di atas simphysis, teraba ballottement $(+)$, dan tidak ada nyeri tekan. Berdasarkan rumus Naegle, usia kehamilan ibu dari hari pertama haid terakhir tanggal 20-02 2018 sampai tanggal pengkajian 27-05- 2018 adalah 13 minggu 5 hari. 
Hiperemesis gravidarum adalah keadaan dimana penderita mual dan muntah lebih dari 10 kali dalam 24 jam, sehingga pekerjaan sehari-hari terganggu dan keadaan umum menjadi buruk. Keadaan ini rata-rata muncul pada usia kehamilan 8-12 minggu (Susilawati dan Erlina, 2017).

Hiperemesis gravidarum adalah mual dan muntah yang terjadi pada ibu hamil yang disebabkan karena meningkatnya hormon estrogen dan HCG (Hormon Chorionic Gonadothrophin) dalam serum. Pada umumnya wanita dapat menyesuaikan keadaan ini, meskipun demikian gejala mual dan muntah yang berat dapat berlangsung sampai 4 bulan. Pekerjaan sehari-hari menjadi terganggu dan keadaan umum menjadi buruk (Nadyah, 2013: $38)$.

Hiperemesis gravidarum disebabkan oleh perubahan hormonal yang menyebabkan masalah pada saluran pencernaan dan memicu mual- mual, muntah, anemia, mudah tersinggung dan tidak bersemangat. Ketidak-nyamanan ini bisa diatasi dengan cara mengubah pola makan. Makanan sehat sangat diperlukan oleh ibu hamil muda karena pada masa awal kehamilan janin sangat rentan untuk bisa mengalami keguguran. Karena itu kondisi ibu yang sedang hamil muda benar-benar harus dijaga, baik kesehatan fisik, kandungan, serta kenyamanan batinnya. Ibu hamil sering mengabaikan. kebutuhan gizi karena mual dan muntah merupakan suatu hal yang tidak nyaman dan mengganggu aktifitas sehari-hari (Ratna Dwi, 2014).

Hiperemesis gravidarum adalah mual dan muntah berlebihan yang terjadi kira-kira sampai umur kehamilan 20 minggu. Ketika umur kehamilan 14 minggu (trimester pertama), mual dan muntah yang dialami ibu begitu hebat. Semua yang dimakan dan diminum ibu dimuntahkan sehingga mempengaruhi keadaan umum dan pekerjaan sehari-hari ibu. Berat badan menurun, terjadi dehidrasi, terdapat aseton dalam urine (Hutahaen, S, 2013: 56). Sedangkan menurut (Andria, 2017), mual dan muntah berlebihan yang dimulai antara usia kehamilan 4-10 minggu, kemudian hilang sebelum usia kehamilan 20 minggu, serta memerlukan intenvensi khusus disebut hiperemesis gravidarum. Terjadi pada 0,3-3\% ibu hamil, hiperemesis gravidarum berkaitan dengan dehidrasi, ketidakseimbangan elektrolit, dan penurunan berat badan hingga $10 \%$ berat badan sebelum hamil, dan tidak boleh disalah artikan dengan gejala mual dan muntah selama kehamilan yang biasanya akan hilang dengan sendirinya. 
Menurut (Indrayani Triana, 2018), keluhan mual dan muntah terjadi pada $60-40 \%$ multigravida. Satu diantara seribu kehamilan gejala-gejala ini menjadi lebih berat. Perasaan mual ini disebabkan oleh karena meningkatnya kadar hormone estrogen dan Hormon Chorionic Gonadothrophin (HCG) dalam serum. Perubahan fisiologis kenaikan hormon ini belum jelas, mungkin karena sistem saraf pusat atau pengosongan lambung yang berkurang.

Dalam penelitian yang dilakukan oleh (Anggasari Yasi, 2016) menyatakan bahwa dari 21 ibu hamil yang berkunjung di BPM Kusmawati, sebagian besar $(71,4 \%)$ mengalami mual muntah pada kehamilan sebelumnya. Ibu hamil yang mengalami mual muntah pada kehamilan sebelumnya cenderung akan mengalami mual muntah pada kehamilan selanjutnya. Hal ini diakibatkan karena stressor ibu yang merasa bahwa dirinya akan mengalami mual muntah yang sama dengan kehamilan yang lalu. Selain itu, peningkatan kadar hormon estrogen dan progesteron akan lebih besar pada kehamilan berikutnya. Menurut (Hutahaen, S, 2013: 68), penyebab hiperemesis gravidarum belum diketahui, akan tetapi interaksi kompleks dari faktor biologis, psikologis, dan sosial budaya diperkirakan menjadi penyebab hiperemesis gravidarum. Selain itu, kehamilan multipel, perempuan dengan kehamilan pertama, usia $<20$ tahun dan $>35$ tahun, kehamilan mola, serta berat badan berlebih menjadi pencetus pada beberapa penelitian.

Hal ini sejalan dengan penelitian yang dilakukan oleh (Sastri Nen, 2017), mengatakan bahwa ibu hamil lebih beresiko menderita hiperemesis gravidarum pada umur $<20$ dan $>35$ tahun. Pada ibu yang berumur $<20$ tahun, secara fisiologis dan fungsional rahim belum sepenuhnya berfungsi secara optimal dan secara psikologis belum siap untuk hamil dan menjadi orang tua. Sehingga ini bisa menjadi konflik mental yang membuat ibu tidak memperhatikan asupan nutrisinya yang menyebabkan iritasi lambung sehingga menimbulkan reaksi pada impuls motorik untuk memberi rangsangan pada pusat muntah. Sedangkan untuk ibu yang umurnya $>35$ tahun mengakibatkan terjadinya penurunan fungsi termasuk organ reproduksi dan secara psikologis ibu merasa tidak sanggup lagi untuk hamil.

\section{B. Langkah II : Identifikasi Diagnosa/ Masalah Aktual}

Diagnosis didasarkan pada tanda dan gejala yang dialami ibu. Untuk mendiagnosis hiperemesis gravidarum (HEG) tidak sukar. Karena didasarkan pada kondisi mual dan muntah secara terus menerus sehingga mempengaruhi keadaan umum dan mengganggu 
aktifitas sehari-hari ibu hamil. Sebagai bidan, kita harus mampu mengenali tanda dan gejala HEG sehingga dapat dilakukan upaya pencegahan dan deteksi dini serta melakukan asuhan kebidanan sesuai dengan keluhan ibu (Irianti, Erda, dkk. 2013: 70).

Teori di atas sesuai dengan kasus yang dialami oleh Ny "S", di mana ibu mengalami mual muntah dengan frekuensi yang sangat sering hingga mencapai \pm 10 kali dalam 24 jam. Hal tersebut mengganggu aktifitas ibu dan mempengaruhi keadaan umumnya. Sehingga ibu dan keluarga memutuskan untuk ke RS agar diberikan penanganan yang tepat, karena ibu sudah sangat lemas. Selain itu, ibu juga merasa pusing dan nyeri ulu hati.

Hasil pemeriksaan fisik yang dilakukan antara lain : tekanan darah ibu 80/60 $\mathrm{mmHg}$, BB ibu $52 \mathrm{~kg}$ (BB sebelumnya $55 \mathrm{~kg}$ ), mata tampak cekung, konjungtiva pucat, sklera sedikit ikterus, bibir kering, dan lidah tampak kotor. Berdasarkan data tersebut, Ny "S" didiagnosa mengalami hiperemesis gravidarum tingkat II.

\section{Langkah III : Identifikasi Diagnosa/ Masalah Potensial}

Hiperemesis gravidarum dapat menyebabkan dehidrasi, turgor kulit berkurang, hiponatremia dan selanjutnya terjadi hemokosentrasi hingga aliran darah ke jaringan berkurang. Hal ini bisa diatasi dengan cara menghilangkan rasa takut karena kehamilan, mengurangi pekerjaan serta menghilangkan masalah dan konflik yang dapat menjadi latar belakang penyakit ini, karena hiperemesis gravidarum dapat mempengaruhi kesehatan ibu dan perkembangan janin (Aquari Bina, 2017).

Mual dan muntah pada kehamilan berlebih atau hiperemesis gravidarum tidak hanya mengancam kehidupan ibu hamil, namun juga dapat menyebabkan efek samping pada janin seperti abortus, bayi berat lahir rendah, kelahiran prematur, serta malformasi pada bayi baru lahir. Kejadian pertumbuhan janin terhambat (Intrauterine Growth Retardation/IUGR) meningkat pada wanita hamil dengan hiperemesis gravidarum (Ardani, 2013).

Hiperemesis gravidarum yang terus-menerus dapat menyebabkan kekurangan makanan yang dapat mempengaruhi perkembangan janin, sehingga pengobatan perlu segera dilakukan (Nadyah, 2013: 41). 


\section{Langkah IV : Tindakan Emergency atau Kolaborasi}

Hiperemesis gravidarum dapat menjadi kasus yang membutuhkan tindakan segera jika ibu mengalami dehidrasi. Namun, pada kasus Ny "S", ibu belum mengalami dehidrasi, sehingga tindakan yang dilakukan disini adalah memasang infus RL 28 tpm pada pukul 12.50 wita. Ini bertujuan untuk mencegah terjadinya dehidrasi. Selain itu, menganjurkan ibu agar tetap berdoa kepada Allah SWT dan banyak berdzikir. Ini juga dapat membantu ibu agar tidak terlalu cemas dalam menghadapi keluhannya.

\section{E. Langkah V : Intervensi}

Intervensi yang diberikan adalah menyampaikan hasil pemeriksaan serta memberitahu ibu dan keluarga bahwa harus dilakukan rawat inap agar ibu mendapatkan perawatan yang tepat untuk mencegah terjadinya komplikasi yang berbahaya bagi ibu dan janinnya. Kemudian, melakukan pemasangan infus dengan cairan RL 28 tpm untuk mencegah terjadinya dehidrasi dan membantu mengganti cairan yang hilang.

Setelah dilakukan pemasangan infus dengan cairan RL 28 tpm pada pukul 12.50 wita di RS TNI-AL Jala Ammari, yaitu di ruangan Mawar, maka selanjutnya memberikan cairan dan obat-obatan sesuai hasil kolaborasi dengan dokter, yakni : Mengganti cairan RL menjadi cairan Ka-en MG 340 tpm pada pukul 13.30 wita. Ka-en MG 3 ini mengandung natrium, kalium, klorida, lactate, dan glukosa. Cairan ini berfungsi untuk membantu pengobatan ketidakseimbangan karbohidrat dan elektrolit pada keadaan infusiensi asupan makanan per oral, prosedur pembedahan, dan neonatologi.

Selanjutnya, melakukan injeksi ranitidin $1 \mathrm{amp} / \mathrm{IV} / 8$ jam pada pukul 14.00 wita. Setelah itu, melakukan injeksi ondansetron $1 \mathrm{amp} / \mathrm{IV} / 8$ jam pada pukul 14.00 wita. Lalu, mengganti cairan Ka-en MG 3 menjadi Pan Amin G 500 ml 40 tpm pada pukul 21.30 wita. Selanjutnya, mengganti cairan Pan Amin G menjadi cairan RL dengan drips Neurobion 1 amp/ 24 jam, 28 tpm pada pukul 05.00 wita. Neurobion merupakan suplemen vitamin yang mengandung vitamin B kompleks yang tinggi, yaitu vitamin B1, B6, dan B12.

Selain itu, menganjurkan ibu untuk mengkonsumsi makanan yang bergizi seimbang, makan dengan porsi sedikit tapi sering, makan makanan selingan seperti roti dan biskuit, banyak minum air putih, istirahat yang cukup, mengobservasi tanda-tanda vital, 
mengobservasi muntah dan urine, menganjurkan ibu untuk berdoa dan berdzikir kepada Allah SWT serta memberikan dukungan psikologis pada ibu agar tidak menjadikan kehamilannya sebagai beban, sehingga tidak memperparah kondisi ibu.

Adapun obat-obatan yang dianjurkan untuk dikonsumsi ibu hamil dengan hiperemesis gravidarum diantaranya vitamin, antiemetik (anti muntah), dan antihistamin (anti alergi). Vitamin yang dianjurkan adalah vitamin B1, B2 dan B6.

\section{F. Langkah VI : Implementasi}

Langkah ini merupakan pelaksanaan dari intervensi atau rencana asuhan yang telah direncanakan secara menyeluruh pada langkah V. Dalam melakukan asuhan, senantiasa berdoa kepada Allah, karena atas izin-Nya lah sehingga ibu dapat sembuh.

\section{G. Langkah VII : Evaluasi}

Pada kasus Ny "S" dilakukan asuhan selama 3 hari di RS. Kemudian dilanjutkan ketika ibu sudah pulang ke rumah sebanyak 5 kali kunjungan. Setelah dilakukan asuhan kebidanan di RS maupun kunjungan di rumah pasien, tidak ditemukan adanya kesenjangan antara teori dan kasus, tidak ada kelainan maupun komplikasi dari hiperemesis gravidarum tingkat II itu sendiri. Ibu sudah tidak mengalami mual dan muntah lagi, merasa sehat dan sudah mampu melakukan aktifitas sehari-hari seperti biasanya. Sehingga ibu sudah mulai merasa nyaman dalam menjalani kehamilannya. Hal ini tentunya tidak terlepas dari izin Allah SWT yang senantiasa memberikan kebaikan berupa nikmat kesembuhan bagi ummatnya yang meminta pertolongan kepada-Nya percaya dan yakin pada Allah bahwa setiap penyakit mempunyai obat. Termasuk memperbanyak dzikir

\section{KESIMPULAN DAN SARAN}

\section{A. KESIMPULAN}

1. Telah dilaksanakan pengkajian dan analisis data sehingga ditemukan data subjektif dan objektif pada Ny "S". Data subjektif yang ditemukan yaitu ibu mengeluh mual dan muntah sebanyak \pm 10 kali dalam sehari yang mengganggu aktifitas dan keadaan umum ibu, ibu memuntahkan semua makanan yang dimakan sehingga ibu menjadi malas makan, ibu merasa lemas, serta nyeri ulu hati. Sedangkan data objektifnya yaitu 
keadaan umum lemah, kesadaran apatis, turgor kulit kurang baik, tekanan darah 80/60 mmHg, mata cekung, sklera sedikit ikterus, konjungtiva pucat, bibir kering, dan lidah tampak kotor.

2. Telah dirumuskan diagnosa/ masalah aktual pada Ny "S" di RS TNI-AL Jala Ammari berdasarkan interpretasi data yang telah dilakukan, yaitu GIII PII A0, gestasi 12-14 minggu, intrauterin, tunggal, keadaan ibu lemah dengan hiperemesis gravidarum tingkat II.

3. Telah dirumuskan diagnosa/ masalah potensial pada Ny "S" dengan hiperemesis gravidarum tingkat II di RS TNI-AL Jala Ammari, yaitu dapat terjadi hiperemesis gravidarum tingkat III, anemia, dehidrasi, serta gangguan pertumbuhan dan perkembangan janin. Namun, pada kasus ini diagnosa potensial atau komplikasi tersebut tidak terjadi karena telah diberikan asuhan dan pemantauan yang sesuai, sehingga kondisi ibu bisa membaik.

4. Telah dilaksanakan perlunya tindakan segera pada $\mathrm{Ny}$ "S" dengan hiperemesis gravidarum tingkat II di RS TNI-AL Jala Ammari, yaitu memasang infus RL 28 tpm pada pukul 12.50 wita, ini berguna untuk mencegah terjadinya dehidrasi pada ibu dan membantu mengganti cairan yang hilang.

5. Telah dilaksanakan rencana asuhan atau intervensi pada $\mathrm{Ny}$ "S" yaitu melakukan rawat inap di RS, melakukan kolaborasi dengan dokter mengenai tindakan dan pemberian obat, menganjurkan ibu makan makanan yang bernutrisi seperti mengandung karbohidrat dan protein yang tinggi, menganjurkan ibu untuk makan sedikit tapi sering, makan makanan selingan seperti biskuit dan roti kering, menganjurkan ibu agar banyak minum air putih, istirahat yang cukup, mengobservasi mual dan muntah, mengobservasi pengeluaran urine, mengobservasi tanda-tanda vital (TTV), serta memberikan dukungan psikologis dan spiritual agar senantiasa berdoa dan berdzikir kepada Allah SWT.

6. Telah dilaksanakan asuhan atau implementasi pada $\mathrm{Ny}$ "S" dengan hiperemesis gravidarum tingkat II di RS TNI-AL Jala Ammari sesuai dengan rencana asuhan yang telah disusun dan sesuai syariat islam. Seperti berdoa dan memperbanyak dzikir kepada Allah SWT saat melakukan tindakan agar senantiasa diberikan kemudahan dalam membantu proses penyembuhan ibu. 
7. Telah dilaksanakan evaluasi terhadap hasil asuhan yang telah dilakukan pada Ny "S" dengan hiperemesis gravidarum tingkat II di RS TNI-AL Jala Ammari, tidak ditemukan adanya kelainan maupun komplikasi. Sehingga ibu dapat menjalani kehamilannya dengan sehat dan nyaman.

8. Telah dilaksanakan pendokumentasian terhadap semua temuan dan tindakan yang telah diberikan pada Ny "S" dengan hiperemesis gravidarum tingkat II di RS TNI-AL Jala Ammari

\section{B. SARAN}

\section{Bagi Prodi Kebidanan}

Diharapkan agar prodi kebidanan semakin meningkatkan mutu dan kualitas pembelajaran bagi mahasiswa. Sehingga mahasiswa dapat menerapkan hal tersebut di lahan praktik serta memberikan asuhan yang tepat sehingga dapat mengantisipasi terjadinya komplikasi. Termasuk pada kasus hiperemesis gravidarum tingkat II.

2. Bagi Tenaga Kesehatan

Diharapkan agar tenaga kesehatan khususnya bidan mampu memberikan asuhan kebidanan yang tepat dan sesuai wewenangnya dalam menghadapi kasus hiperemesis gravidarum tingkat II dengan tetap menerapkan integrasi keislaman di dalamnya.

3. Bagi Penulis

Diharapkan agar penulis semakin meningkatkan wawasan keilmuan dan pengalaman yang dimiliki agar semakin mahir dalam menangani kasus kebidanan, termasuk pada kasus hiperemesis gravidarum tingkat II.

4. Bagi Ibu dan Keluarga

a. Diharapkan agar dapat menambah pengetahuan ibu hamil terkait hal- hal yang bisa terjadi selama kehamilan, termasuk kasus hiperemesis gravidarum tingkat II.

b. Diharapkan ibu dapat mengenali kelainan atau tanda bahaya pada ibu hamil dan segera ke pusat pelayanan kesehatan jika mengalaminya. Dengan demikian, dapat diberikan penanganan secepat mungkin dan mencegah terjadinya komplikasi.

c. Diharapkan agar ibu banyak berdoa dan berdzikir kepada Allah SWT agar senantiasa diberikan kesehatan selama kehamilan hingga persalinnya kelak. 
d. Diharapkan agar keluarga dapat membantu proses penyembuhan ibu dengan hiperemesis gravidarum. Seperti memberikan support dan menjaga kondisi psikologis ibu sehingga ibu dapat menjalani kehamilannya dengan nyaman

\section{DAFTAR PUSTAKA}

Andria, "Pengetahuan Ibu Hamil Tentang Hiperemesis gravidarum di Rumah Sakit Umum Daerah Rokan Hulu", Jurnal Maternity and Neonatal, Vol 2, No 3, 2017.

Anggasari Yasi, " Kejadian Hiperemesis gravidarum Ditinjau dari Riwayat Penggunaan Kontrasepsi Hormonal Saat Pra Konsepsi Di Bpm Kusmawati Surabaya”, Fakultas Keperawatan dan Kebidanan, Vol 9, No 1, Februari 2016.

Aquari Bina, "Faktor-faktor yang Mempengaruhi Kejadian Hiperemesis gravidarum (HEG) di Puskesmas Sosial Palembang Tahun 2017”, Akademi Kebidanan Budi Mulia Palembang, Vol 5 No 1, Juni 2017.

Atika, Hadrians, dkk, "Hubungan Hiperemesis gravidarum dengan Usia Ibu, Usia Gestasi, Paritas, dan Pekerjaan pada Pasien Rawat Inap di RSUP Dr. Moh. Hoesin Palembang”, Jurnal Kedokteran dan Kesehatan, Vol 3, No 3, 2016.

Ardani Ayu, "Perbandingan Efektifitas Pemberian Terapi Minuman Jahe dan Minuman Kapulaga Terhadap Morning Sickness pada Trimester I di Kelurahan Ngempon Kecamatan Bergas Kabupaten Semarang", 2013.

Bothamley dan Maureen, 2013. Patofisiologi dalam Kebidanan. Jakarta : EGC

Darmawansyih, 2014. Penyakit Kronik dalam Kehamilan. Makassar: Alauddin University Press

Dewi, 2012. Asuhan Kebidanan pada Ibu Hamil Normal dan Patologi. Yogyakarta : Nuha Medika

Fadlun dan Achmad, 2013, Asuhan Kebidanan Patologis. Jakarta: Salemba Medika

Heriani, "Hubungan Sikap Terhadap Peran dan Pendampingan Suami dalam Pemeriksaan Kehamilan Terhadap Hiperemesis gravidarum di Rumah Sakit Umum Daerah Dr. Ibnu Soetowo Baturaja Tahun 2014", STIKES Al- Ma'arif Baturaja Program Studi DIII Kebidanan, Vol 2, No 1, September 2016.

Hutahaen, 2013. Perawatan Antenatal. Jakarta : Salemba Medika

Indrayani Triana, "Faktor-faktor yang Berhubungan dengan Hiperemesis gravidarum di RSUD Dr. Drajat Prawinegara Kabupaten Serang Tahun 2017', Jurnal Akademi Keperawatan Husada Karya Jaya, Vol 4, No 1, Maret 2018.

Irianti, Erda, dkk. 2013. Asuhan Kehamilan Berbasis Bukti. Jakarta : CV Agung Seto

Izaanatul Fakhriyanti, "Perilaku Ibu Hamil dalam Pencegahan Hiperemesis gravidarum di BPM Ny. E di Desa Grinting Kecamatan Tulangan Kabupaten Sidoarjo”, 24 Mei 2014.

Jannah, 2012. Buku Ajar Asuhan Kebidanan.Yogyakarta : CV. Andi Offset

Masriroh, 2013. Keperawatan Obstetri dan Ginekologi. Yogyakarta : Imperium

Medforth, Susan, dkk. 2014. Kebidanan Oxford dari Bidan untuk Bidan. Jakarta: EGC

Mitchell, Gallos, dkk, "Psycological Morbidity Associated with Hiperemesis gravidarum : A Systematic Review and Meta-Analysis", An International Journal of Obstetrics and Gynaecology, 2016.

Muhammad Abu, 2010. Tuntunan Praktis dan Padat bagi Ibu Hamil dari A sampai Z, Pustaka Ibnu Umar. 
Nadyah, 2013. Kegawatdaruratan Neonatal, Anak dan Maternal. Makassar : Alauddin University Press

Prawirohardjo, Sarwono. 2014. Ilmu Kebidanan. Jakarta : PT Bina Pustaka Sarwono Prawihardjo

Puspito, 2012. Kitab Kehamilan dan Persalinan. Yogyakarta : Mitra Buku

Rahma Marliana dan Tita, "Asuhan pada Ibu Hamil Trimester I dengan Hiperemesis Gravidarum Tingkat I", Jurnal Bidan, Vol 2, No 2, Juli 2016.

Ratna Dwi, "Faktor Resiko Hiperemesis gravidarum pada Ibu Hamil di Puskesmas Kapongan Kecamatan Kapongan Situbondo", Juni 2014.

Salafudin M, Triana, dkk, "Hubungan Antara Dukungan Suami dengan Kejadian Hiperemesis Gravidarum di Polindes Desa Nolokerto Kecamatan Kaliwungu Kabupaten Kendal", Vol 7, No 2, Januari 2017.

Sastri Nen, "Analisis Kejadian Hiperemesis gravidarum pada Ibu Hamil Di Bidan Praktik Mandiri Ellna Palembang Tahun 2017”, Program Studi Kebidanan Sekolah Tinggi Ilmu Kesehatan Bina Husada, Vol 5, No 2, Desember 2017.

Setiawati, 2013. Kehamilan dan Pemeriksaan Kehamilan. Makassar : Alauddin University Press

Sunarti, 2013. Asuhan Kehamilan. Jakarta : Penerbit In Media

Susilawati dan Erlina, "Hubungan Gravida, Umur, dan Pendidikan Ibu dengan Hiperemesis gravidarum”. Jurnal Obstetrika Scientia, 2017.

Shihab Quraish, 2012. Tafsir Al-Misbah. Jakarta : Lentera Hati

Yeyeh, Lia. 2013. Asuhan Kebidanan I Kehamilan. Jakarta : CV. Trans Info Media 